\title{
Zur Kenntnis von Septoria nodorum Berk., dem Erreger der Spelzenbräune und einer Blattdürre des Weizens
}

\section{Doctoral Thesis}

Author(s):

Brönnimann, Alfred

Publication date:

1968

Permanent link:

https://doi.org/10.3929/ethz-a-000089014

Rights / license:

In Copyright - Non-Commercial Use Permitted 
Diss. ET H

Diss. Nr. 3989 B.

\title{
Zur Kenntnis von Septoria nodorum Berk., dem Erreger der Spelzenbräune und einer Blattdürre des Weizens
}

\author{
ABHANDLUNG \\ ZUR ERLANGUNG
}

DER WURDE EINES DOKTORS DER

TECHNISCHEN WISSENSCHAFTEN

DER

EIDGENOSSISCHEN TECHNISCHEN

HOCHSCHULE IN ZURICH

VORGELEGT VON

\section{ALFRED BROONNIMANN}

DIPL. ING.-AGR. ETH

GEBOREN AM 5.1.1936

VON KOONIZ, KT. BERN

Angenommen auf Antrag von

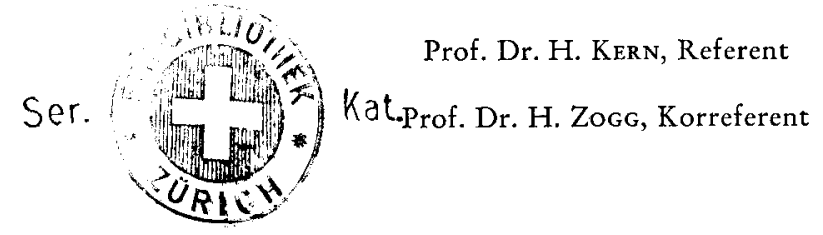


renz zwischen der Kornausbildung infizierter und nichtinfizierter Pflanzen ausschlaggebend. Aufgrund der Ergebnisse des Sortenversuches dürfen Zuchtstämme, bei denen diese Differenz höchstens zwei Beurteilungseinheiten beträgt, als brauchbar betrachtet werden (vgl. Tab. 13, Kornbesch.: I-K mit Abb. 18). Bei den nach dieser Methode ausgewählten Zuchtstämmen kann für eine schärfere Selektion zusätzlich das relative Tausendkorngewicht bestimmt werden.

Die Anforderungen, welche an eine ideale Selektionsmethode gestellt werden, sind in dem vorgeschlagenen Weg nur teilweise erfüllt. Die Selektion erfolgt erst nach der Ernte, weshalb eine weitere züchterische Bearbeitung nur am nachgebauten Material möglich ist. Die Methode läßt ferner Zuchtstämme unberücksichtigt, welche unter natürlichen Bedingungen infolge beschleunigter Entwicklungsrhythmen einem starken Befall durch Septoria nodorum entfliehen. Schließlich ist sie nur in Gebieten anwendbar, in denen eine massive natürliche Infektion normalerweise ausbleibt, da sonst die zum Vergleich benötigten nicht infizierten Pflanzen spontan befallen werden. Die beschriebene Methode ist jedoch in ihrer Durchführung relativ einfach und daher geeignet, große Serien zu prüfen. Sie bedarf noch der Erprobung in der praktischen Resistenzzüchtung.

\section{Zusammenfassung}

1. Die Stämme von Septoria nodorum wiesen große Schwankungen in der Sporenproduktion, jedoch keine gesicherten Unterschiede in ihrer Pathogenität auf.

2. Eine Infektion gelang bei geeigneten Umweltbedingungen nur mit Sporensuspensionen der Konzentration von mindestens $10^{3}$ Sporen $/ \mathrm{ml}$. Bei Infektionen im Freiland stieg die Schädigung des Tausendkorngewichtes mit zunehmender Sporenkonzentration und verursachte bei der Konzentration 108/ml einen Ausfall von $45,5 \%$.

3. Infektionen im Herbst oder während der Vegetationsruhe führten bei Winterweizen zu einer schwachen Erkrankung im Frühjahr und zu Sekundärinfektionen während und nach der Blüte. Die von den Blattscheiden umhüllte Ahre ist gegenüber Infektionen weitgehend, aber nicht vollständig, geschützt. Starken Befall an Blatt und Ahre verursachten Infektionen nach dem Ahrenschieben.

4. Von den untersuchten Ertragskomponenten wurden bei Septoria-Befall das Tausendkorngewicht stark, die Kornzahl je Ahre weniger beeinflußt. Die Auswirkungen des Parasiten auf den Ertrag wurden deshalb am Tausendkorngewicht gemessen.

5. Die größten Ertragsausfälle entstanden bei Infektion zwischen Beginn des Ahrenschiebens und dem Ende der Blüte. Sie betrugen im Maximum 46,4\% bei Winterweizen und $40,4 \%$ bei Sommerweizen.

6. Bei Infektion der Ahre und der obersten drei Blätter betrug der Gesamtschaden $65,1 \%$. Dabei waren $29,0 \%$ auf den Befall der Ähre, 22,9\% auf denjenigen des obersten, $6,1 \%$ des zweiten und 7,1\% des dritten Blattes zurückzuführen. 
7. Die Prüfung der Reaktion mehrerer Sorten auf den Befall ergab Toleranzen bei den einen und Empfindlichkeiten bei anderen Sorten. Die Ertragsverminderung lag zwischen $25,3 \%$ und $48,5 \%$ und betrug im Durchschnitt $37,4 \%$.

8. Werden bei der einzelnen Sorte mehrere Befallsstufen berücksichtigt, so ergeben sich gesicherte Beziehungen zwischen dem Befall in verschiedenen Entwicklungsstadien und der Schädigung des Weizens. Bei einmaliger Infektion mehrerer Sorten gestattet die Befallsbeurteilung auf dem Feld dagegen keine Aussage über die zu erwartende Schädigung.

9. Das Ausmaß des Befalles der Körner ist bei geeigneten Umweltbedingungen von der Sporenkonzentration des Parasiten und dem Entwicklungsstadium des Weizens zur Zeit der Infektion abhängig.

10. Die Verwendung von befallenem Ausgangssaatgut wirkt sich nur dann schädigend auf das Erntegut aus, wenn während des Wachstums der Pflanzen die Umweltbedingungen für den Parasiten günstig sind. Eine chemische Beizung verhindert die Übertragung von Septoria nodorum durch das Samenkorn weitgehend.

11. Befallene Ernterückstände sind als Infektionsquellen von besonderer Bedeutung, da der Pilz insbesondere bei genügender Feuchtigkeit während längerer Zeit Sporen bildet.

12. Die züchterische Bearbeitung muß sich vorerst auf die Auslese toleranter Zuchtstämme beschränken. Als Maß für die Toleranz wird das Tausendkorngewicht des infizierten Zuchtstammes, ausgedrückt in Prozent der nicht infizierten Kontrolle, vorgeschlagen. Anstelle des Tausendkorngewichtes kann auch die Differenz in der Kornbeschaffenheit zwischen infizierten und gesunden Pflanzen benützt werden.

\section{Summary}

\section{On Septoria nodorum Berk., the Pathogen Causing "Leaf Blotch" and} "Glume Blotch" of Wheat

1. The individual isolates of Septoria nodorum showed large differences in spore production, but no statistically significant differences were found concerning their pathogenicity.

2. Artificial infection of the host plant was only possible with spore suspensions having a concentration of at least $10^{3}$ spores $/ \mathrm{ml}$ inoculated in favourable environmental conditions. The infections in the field showed larger reductions of the thousand grain weight with increasing spore concentration. At a spore concentration of $10^{8}$ spores $/ \mathrm{ml}$ a weight decrease of $45.5 \%$ was observed.

3. Infections of winter wheat produced in the autumn or during the winter resulted in only a weak manifestation of the disease in the spring, but secondary infections occurred during the flowering stage. The ear, when it is still covered by the sheath of the last leaf, is almost completely protected against infection. A heavy attack of the leaves and ears occurred from infection during the heading stage of the host plant. 
4. Within the yield components examined, the thousand grain weight was very strongly influenced by infection with Septoria, whereas the number of grains per ear was less affected. Estimation of the attack by the parasite was, therefore, based on the thousand grain weight.

5. The largest yield losses were observed when the infection took place during the heading stage (beginning of ear emergence until flowering). The largest losses noted were $46.4 \%$ with winter wheat and $40.4 \%$ with spring wheat.

6. When the ear and the three youngest leaves of the plant were infected, the total loss was $65.1 \%$. This figure is composed of $29.0 \%$ loss due to infection of the ear, $22.9 \%$ due to the infection of the youngest leaf, $6.1 \%$ due to the second youngest leaf and $7.1 \%$ due to the third youngest leaf.

7. Examination of different varieties for fungus reaction showed tolerance in some hosts and susceptible reactions in others. The yield decrease varied between $25.3 \%$ and $48.5 \%$, the average decrease being $37.4 \%$.

8. A significant relation between infection at different growth stages of the wheat plant and the damage of the thousand grain weight can be found, if all degrees of attack of the specific variety are included in the evaluation. But with a single infection of several varieties the yield loss cannot be predicted from field estimation of the disease.

9. The amount of infected grains (in favourable environmental conditions) depends on the spore concentration of the fungus and the growth stage of the wheat plant at the time of infection.

10. Damage to the crop, if infected seed is used, is only found if the environmental factors are favourable for the development of the parasite during the growth period of the host plant. Seed treatment decreases the spreading of Septoria nodorum to a large degree.

11. Residual infected plant pieces in the field after harvesting present a great danger for infection of the next crop, since the fungus can produce spores for a long period of time if the humidity level is high enough.

12. Breeding work is for the moment restricted to the selection of tolerant lines. It is suggested that the thousand grain weight of the infected line, expressed as a percentage of the non-infected control, is used for the estimation of tolerance. Differences in the grain characteristics of infected and healthy plants may also be used in addition to the thousand grain weight.

\section{Résumé}

Contribution à l'étude de Septoria nodorum Berk., agent du brunissement des glumes et d'un dessèchement des feuilles du blé

1. Les souches de Septoria nodorum présentent de grandes variations dans la production de spores, mais on n'a pas constaté de différences significatives dans leur pathogenécité. 
2. Dans des conditions ambiantes appropriées, une infection n'a réussi qu'avec des suspensions de spores à la concentration minimale de $10^{3} \mathrm{spores} / \mathrm{ml}$. Dans les infections en plein champ, l'effet sur le poids de 1000 grains augmente avec la concentration des spores. La diminution du poids de 1000 grains atteint $45,5 \%$ à la concentration de $10^{8}$ spores $/ \mathrm{ml}$.

3. Sur le blé d'automne les infections en automne ou pendant le repos de la végétation causent une faible attaque au printemps et des infections secondaires pendant et après la floraison. Avant l'épiaison l'épi, enveloppé par les feuilles, est relativement bien protégé contre l'infection. Cette protection n'est cependant pas complète. Les infections après l'épiaison attaquent fortement la feuille et l'épi.

4. Parmi les composantes du rendement qui ont été examinées, l'attaque de Septoria influence fortement le poids de 1000 grains et dans une plus faible mesure le nombre de grains par épi. De ce fait, l'effet du parasite sur le rendement a été mesuré par le poids de 1000 grains.

5. Les plus fortes dépressions de rendement sont observées lorsque l'infection a lieu entre le début de l'épiaison et la fin de la floraison. Elles atteignent 46,4\% chez le blé d'automne et $40,4 \%$ chez le blé de printemps.

6. Lorsque l'infection porte sur l'épi et les 3 dernières feuilles, la perte totale s'élève à $65,1 \%$ dont 29,0\% peuvent être attribués à l'attaque de l'épi, 22,9\% à celle de la dernière, $6,1 \%$ de l'avant-dernière et $7,1 \%$ de la 3ème feuille.

7. En examinant la réaction de diverses variétés on observe des tolérances chez les unes et des sensibilités chez les autres. La dépression de rendement varie entre $25,3 \%$ et $48,5 \%$. Elle est en moyenne de $37,4 \%$.

8. Si l'on tient compte, pour une variété prise individuellement, de plusieurs degrés d'attaque, on constate une relation assurée entre l'attaque observée au champ à divers stades de développement de la plante et les dégâts qui en résultent. Au contraire, lors d'une infection unique portant sur plusieurs variétés, l'appréciation de l'attaque sur le champ ne permet pas de prédire l'importance du dommage.

9. Dans des conditions ambiantes appropriées, l'étendue de l'attaque du grain dépend de la concentration en spores du parasite et du stade de développement du blé au moment de l'infection.

10. L'utilisation de semences infectées n'a d'influence défavorable sur la récolte que si les conditions écologiques sont favorables au parasite pendant la croissance de la plante. La désinfection chimique empêche dans une large mesure la transmission de Septoria nodorum par les semences.

11. Les résidus de récolte malades constituent une importante source d'infection car, si l'humidité est suffisante, le champignon peut encore longtemps former des spores.

12. L'amélioration des variétés doit en premier lieu se limiter à la sélection de lignées tolérantes. Comme mesure de la tolérance, on propose d'utiliser le poids de 1000 grains d'une lignée infectée exprimé en pour cents du contrôle correspondant non infecté. Au lieu du poids de 1000 grains on peut aussi avoir recours à la différence d'aspect du grain entre plantes infectées et saines. 